\title{
Indikator Kesejahteraan di Provinsi Bali: Suatu Pendekatan Analisis Biplot
}

\author{
I Komang Gde Sukarsa ${ }^{1}$ \\ ${ }^{1}$ Program Studi Matematika - Universitas Udayana, INDONESIA \\ Email: gedesukarsa@unud.ac.id \\ GK Gandhiadi ${ }^{2}$ \\ ${ }^{2}$ Program Studi Matematika - Universitas Udayana, INDONESIA \\ Email: gandhiadigk@yahoo.com.
}

\begin{abstract}
The goal of this research is to get the representation of welfare in Bali province based on the indicators represented by People Development Index (PDI). PDI is the index is a latent variable that cannot be measured like measurement variable, so to measure PDI have to be measure by several indi-cators. In general, PDI is measured by three indicators that is a long and healthy life as the Health Indicators, Education Indicators and a decent standard of living as Economic Indicators. In Practice, Health Indicators is measured by the mean expectation of life. Mean of long school and expectation of long school are a measurement of Education Indicators. Whereas Economic Indicators is represented by purchasing power parity. In Statistics methods, to represent or analyze multivariate variable many methods can be used. One of the methods is Biplot. In Biplot analysis, we can represent information about the row matrix and column matrix simultaneous. In these cases, we can get information about the object (9 districts or city in Bali) and Welfare Indicators represented by PDI simultanous. The result of biplot analysis in this research is a two-dimension graphic that represents Euclid distance of object and correlation of indicators so that we can get information of the grouping of the object and the character- istic variables of the certain group.
\end{abstract}

Keywords: Biplot, Group Analysis, People Development Indeks, Welfare Indi-cators

\begin{abstract}
Abstrak: Penelitian ini bertujuan untuk mendapatkan gambaran kesejahteraan di Provinsi Bali berdasar- kan indikator yang direpresentasikan oleh Indeks Pembangunan Manusia (IPM). IPM adalah indeks merupakan variabel laten yang tidak dapat diukur seperti variabel pengukuran, sehingga untuk men- gukur IPM harus diukur dengan beberapa indikator. Secara umum IPM diukur dengan tiga indikator yaitu umur panjang dan sehat sebagai Indikator Kesehatan, Indikator Pendidikan dan Standar Hidup Layak sebagai Indikator Ekonomi. Dalam Prakteknya, Indikator Kesehatan diukur dengan rata-rata harapan hidup. Rata-rata Lama Sekolah dan Harapan Lama Sekolah adalah Ukuran Indikator Pendidi- kan. Sedangkan Indikator Ekonomi diwakili oleh paritas daya beli. Dalam metode Statistika, untuk merepresentasikan atau menganalisa variabel multivariat banyak metode yang dapat digunakan. Salah satu caranya adalah dengan Biplot. Dalam analisis biplot, kita dapat merepresentasikan informasi ten- tang matriks baris dan matriks kolom secara simultan. Dalam hal ini kita dapat memperoleh informasi tentang objek (9 kabupaten atau kota di Bali) dan Indikator Kesejahteraan yang diwakili oleh kesultanan IPM. Hasil analisis biplot dalam penelitian ini berupa grafik dua dimensi yang merepresentasikan jarak Euclid objek dan korelasi indikator sehingga diperoleh informasi pengelompokan objek dan variabel karakteristik dari kelompok tertentu.
\end{abstract}

Keywords: Analisis Gerombol, Biplot, Indikator Kesejahteraan, Indeks Pembangunan Manusia 


\section{Pendahuluan}

\subsection{Latar Belakang}

Amanat Undang- Undang Dasar (UUD) 1945 adalah tercapai kesejahteraan masyarkat. Hal ini dengan sangat jelas tercantum pada Pembukaan atau Mukadimah UUD 1945. Usaha untuk meningkatkan taraf hidup dan kesejahteraan rakyat Indonesia dapat dilakukan dengan cara memperbaiki kondisi indikator - indikator (peubah) kesejahteraan yang oleh Badan Pusat Statistika (BPS) dirilis setiap tahun sebagai bagian dari penyusun Indeks Pembangunan Manuasia (IPM) yang biasanya dijadikan patokan untuk melihat seberapa majunya kesejahteran suatu wilayah.

Data BPS Provinsi Bali Tahun 2007 menunjukkan Indeks Pembangunan Manusia (IPM) masing-masing kabupaten/kota di Propinsi Bali secara rata-rata lebih rendah dibandingkan IPM Nasional. Salah satu cara yang dapat ditempuh pemerintah kota/kabupaten di Provinsi Bali dalam meningkatkan IPM di masing-masing kabupaten/kota adalah dengan menyeimbangkan kondisi-kondisi peubah kesejahteran sebagai penyusun IPM. Keseimbangan yang dimaksudkan adalah meningkatkan nilai/skor peubah yang rendah dan mempertahankan nilai/skor yang tinggi. Upaya untuk menyeimbangkan kondisi dari peubah-peubah ini hanya efektif jika posisi relatif kabupaten/kota dapat diketahui, serta hubungan setiap peuba terhadap peubah lainnya dapat diketahui.

Dalam bidang ilmu Statistika, utamanya pada disiplin Ilmu Peubah Ganda terdapat alat yang dapat menjawab kebutuhan di atas dalam hal menggambarkan posisi relatif kabupaten/ kota serta hubungan antar peubah kesejahteran . Alat yang tepat untuk tujuan tersebut adalah Analisis Biplot Analisis Biplot adalah analisis yang menumpangtindihkan gambaran tentang posisi obyek (kabupaten/ kota dalam kasus ini) dan gambaran tentang peubah (peubah kesejahteran) dalam satu grafik yang nantinya dapat diintepretasikan sebagai posisi obyek dan sekaligus hubungan antar peubah satu dengan yang lain (korelasi antar peubah).

Istilah $b i$ pada biplot dikaitkan dengan peragaan bersama atau serempak antara baris dan kolom matriks dan bukan karena plot yang ditampilkan berdimensi dua (Kroonenberg, 1997). Melalui peragaan ini diharapkan dapat diperoleh gambaran tentang objek, misalnya kedekatan antar objek dan gambaran tentang peubah, baik tentang keragamannya maupun korelasinya, serta keterkaitan antara objek-objek dengan peubah-peubahnya. Dasar peragaan biplot ini menggunakan teknik yang disebut penguraian nilai singular.

Teknik penguraian nilai singular merupakan teknik aproksimasi sedemikian hingga dapat ditemukan ruang berdimensi rendah terbaik bagi matriks data yang berdimensi tinggi. Melalui teknik ini, koordinat-koordinat pada beberapa dimensi yang layak (feasible) dapat diperoleh. Oleh karena itu, penguraian nilai singular merupakan dasar dari peragaan biplot.

\subsection{Penguraian Nilai Singular}

Misalkan $\mathbf{X}$ adalah matriks berukuran $n \times p$ yang berpangkat $r[r \leq \min \{n, p\}]$ maka penguraian nilai singular matriks $\mathbf{X}$ adalah (Watkins, 1991)

$$
\mathbf{X}=\mathbf{U} \boldsymbol{\Lambda} \mathbf{V}^{\prime},
$$

dimana:

$\mathbf{U}$ adalah matriks vektor singular kiri berukuran $n \times n$ dan merupakan vektor eigen dari matriks 
$\mathbf{X X}^{\prime}$

$\mathbf{V}^{\prime}$ adalah transpos dari matriks $\mathbf{V}$ yaitu matriks vektor singular kanan ber- Ukuran $p \times p$ dan merupakan vektor eigen dari $\mathbf{X}^{\prime} \mathbf{X}$;

$\Lambda$ adalah matriks diagonal nilai singular berukuran $n \times p$ yaitu,

$\boldsymbol{\Lambda}=\operatorname{diag}\left(\sqrt{\lambda_{1}}, \sqrt{\lambda_{2}}, \ldots, \sqrt{\lambda_{p}}\right)$ dengan $\lambda_{1} \geq \lambda_{2} \geq \cdots \geq \lambda_{r}>\lambda_{r+1}=\lambda_{\mathrm{r}+2}=\cdots=\lambda_{p}=0$ (Lip-

kovisch dan Smith, 2002)

\subsection{Perumusan Masalah}

Mengacu kepada latar belakang di atas, maka permasalahan yang diidentifikasi pada penelitian ini adalah:

1. Bagaimanakan posisi dari 9 kabupaten/kota di Provinsi Bali ditinjau dari kesamaan ciri peubah-peubah kesejahteraan yang diteliti?

2. Peubah (peubah-peubah) manakah di masing-masing kabupaten/kota yang perlu diprioritaskan pengembangannya sehingga terjadi Tingkat Kesejateraan Masyrakat yang dapat dicerminkan melalui peningkatan IPM

\subsection{Tujuan Penelitian:}

Tujuan dari penelitian ini adalah:

1. Untuk mendapatkan pemetaan posisi kabupaken/kota di Provinsi Bali berdasarkan kesamaan ciri dari peubah kesehteraan yang diteliti;

2. Untuk mengetahui peubah kesejahteraan yang perlu ditingkatkan sehingga peningkatan kesejahteran di suatu kabupaten/kota di Provinsi Bali dapat lebih terarah.

\section{METODE PENELITIAN}

\subsection{Sumber Data dan Peubah Penelitian}

Penelitian ini direncanakan memanfaatkan data hasil Survei Sosial Ekonomi (SUSENAS) tahun terakhir yang dilakukan Badan Pusat Statistik Provinsi Bali, dengan obyek penelitian merupakan 8 kabupaten dan 1 kota di Provinsi Bali.

Peubah-peubah yang diamati didasarkan pada peubah yang masuk ke dalam indikator kesejahteran yng merupakan penyusun IPM yang digunakan oleh BPS, yaitu:

1. Umur Harapan Hidup Saat Lahir (UHH): yaitu jumlah tahun yang diharapkan dapat dicapai oleh bayi yang baru lahir untuk hidup, dengan asumsi bahwa pola angka kematian menurut umur pada saat kelahiran sama sepanjang usia bayi.

2. Harapan Lama Sekolah (HLS): yaitu lamanya (tahun) sekolah formal yang diharapkan akan dirasakan oleh anak pada umur tertentu di masa mendatang.

3. Rata-rata Lama Sekolah (RTS): Rata-rata lamanya (tahun) penduduk usia 25 tahun ke atas dalam menjalani pendidikan formal.

4. Standar Hidup Layak : Standar hidup yang layak digambarkan oleh pengeluaran per kapita disesuaikan, yang ditentukan dari nilai pengeluaran per kapita dan paritas daya beli (purchasing power parity). 


\subsection{Analisis Data}

Adapun tahapan analisis data yang direncanakan adalah:

a. Memperhatikan bahwa terdapat bahwa peubah yang akan diamati di mana satuan amatan untuk seluruh peubah tidak seragam, maka tahapan pertama yang akan dilakukan adalah melakukan standarisasi data;

b. Matrik data yang telah terstandarisasi selanjutnya akan dilakukan peng- uraian nilai singular (Singular Value Decomposition) dengan mengguna- kan persamaan (1) sehingga diperoleh vektor eigen (eigen vector) dan akar ciri (characteristic root) yang menggambarkan besarnya informasi yang terkandung pada masing-masing peubah serta keragaman komponen penciri dari masing-masing vektor eigen;

c. Menentukan koordinat-koordinat dari dimensi peraga biplot;

d. Menginterpretasikan hasil peraga biplot.

e. Pembatan dendogram analisis gerombol

f. Membandingkan hasil biplot dan analisis gerombol

\section{HASIL DAN PEMBAHASAN}

\subsection{Gambaran IPM Bali}

Pembangunan manusia di Bali terus mengalami kemajuan. Pada tahun 2017, Indeks Pembangunan Manusia (IPM) Bali mencapai 74,30. Angka ini meningkat sebesar 0,65 poin atau tumbuh sebesar 0,88 persen dibandingkan tahun 2016. Secara umum gambaran perkembangan IPM Bali dari tahun 2010 sampai dengan 2017 dapat dilihat pada gambar 3.1.1

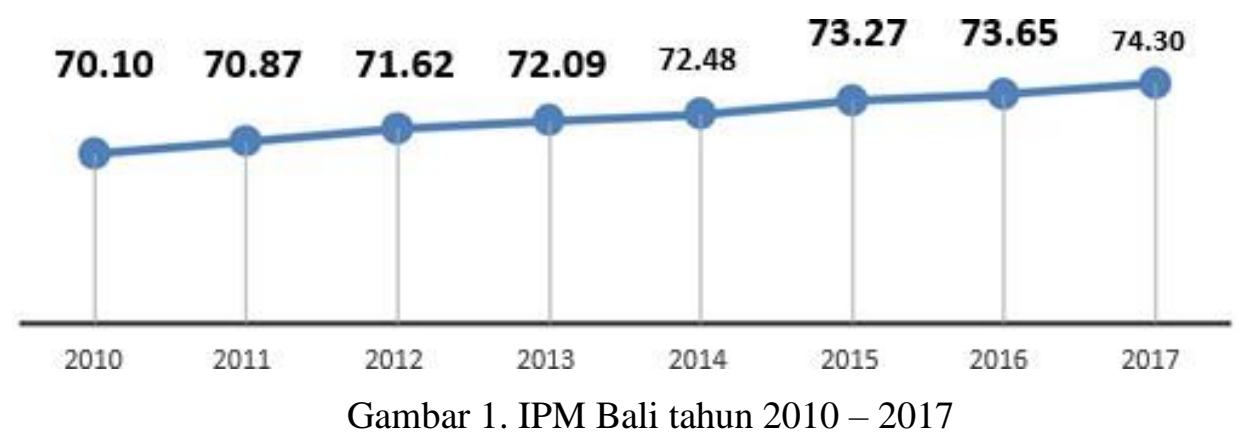

IPM merupakan indikator yang digunakan untuk melihat perkembangan pembangunan dalam jangka panjang. Untuk melihat kemajuan pembangunan manusia, terdapat dua aspek yang perlu diperhatikan, yaitu kecepatan dan status pencapaian. Secara umum, pembangunan manusia Bali terus mengalami kemajuan selama periode 2010 hingga 2017. IPM Bali meningkat dari 70,10 pada tahun 2010 menjadi 74,30 pada tahun 2017. Selama periode tersebut, IPM Bali rata-rata tumbuh sebesar 0,84 persen per tahun dan selalu berada di level "tinggi". Pada periode 2016-2017, IPM Bali tumbuh 0,88 persen. IPM Bali tercatat berada di posisi lima tertinggi secara nasional, di bawah DKI Jakarta, DI Yogyakarta, Kalimantan Timur dan Kepulauan Riau. 
Gambaran yang sama juga terjadi pada setiap kabupaten/kota di Bali. Dari tahun 2010 sampai tahuun 2017 nilai IPM setiap kabupaten/ kota di Bali mengalami peningkatan. Trend dari perkembangan IPM di setiap kabupaten, kota di Bali diperlihatkan pada Gambar 1 dan 3

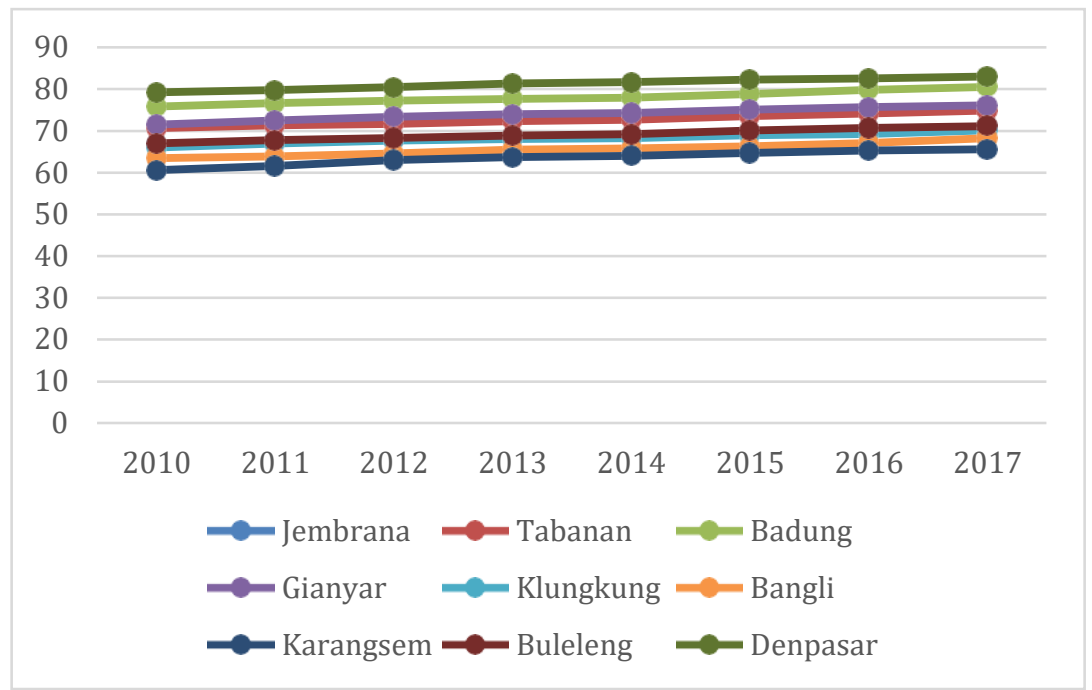

Gambar 2. IPM Kabupaten/Kota di Bali tahun 2010 - 2017

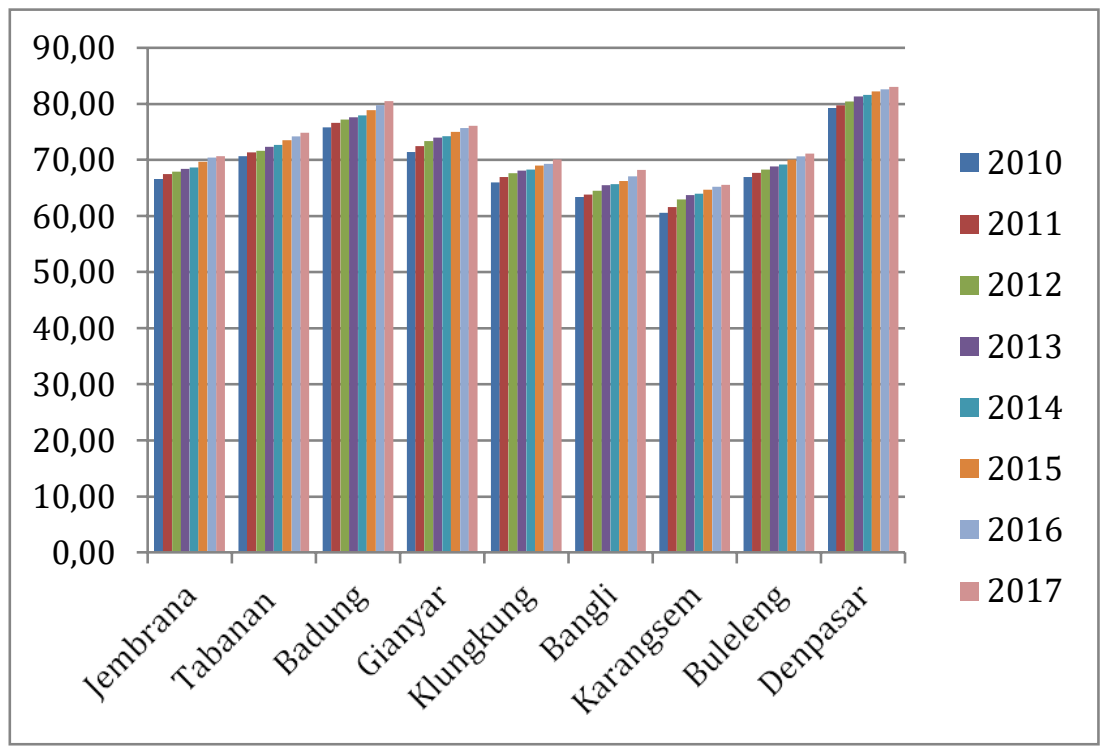

Gambar 3. IPM Kabupaten/Kota di Bali Tahun 2010 - 2017

Dari Gambar 3 terlihat bahwa IPM tertinggi di kabupaten /kota di Bali terjadi di Kabupaten Denpasar dengan IPM pada tahun 2017 sebesar 83,01 dan IPM terendah terjadi di Kabupaten Karangasem sebesar 65,57.

Secara umum berdasarkan kreteria kelompok IPM maka IPM kabupaten/kota di Bali terdiri dari 3 kelompok yaitu kelompok sangat tinggi terdiri dari Kabupaten Badung dan Kota Denpasar ; tinggi terdiri dari Kabupaten Tabanan, Jembrana, Buleleng, Gianyar dan Klungkung dan kelompok sedang terjadi pada Kabupaten Bangli dan Karangasem. Tidak ada satupun kabupaten dan kota di Bali yang masuk kelompok IPM rendah. 


\subsection{Gambaran Indikator Penyusun IPM Bali}

IPM adalah gambaran yang dapat dipakai sebagai salah satu representasi kesejahteraan masyarakat. Tetapi seperti diketahui IPM bukan variabel yang dapat diukur secara langsung (variabel laten). IPM adalah suatu variabel yang disusun oleh 3 (tiga) dimensi atau indicator yaitu dimensi Panjang umur dan Hidup Sehat yang diukur berdasarkan Umur Harapan Hidup (UHH); dimensi pengetahuan yang diukur dengan variabel Harapan Lama Sekolah (HLS) dan Rata-rata Lama Sekolah (RLS) dan dimensi Standar Hidup Layak yang diukur dengan Pengeluaran Perkapita berdasarkan harga konstan 2012. Berdasarkan penjelasan di atas pertanyaan besarnya adalah apakah kabupaten/kota dengan IPM yang berdekatan juga akan memberikan gambaran yang sama jika dilihat dilihat berdasatkan indikator penyusunnya? Secara logika mestinya tidak karena nilai IPM sebesar 70 karena disusun oleh 4 komponen maka bias saja angka 70 dapat diperoleh dari rata - rata angka 70, 70, 65, 75 atau juga 90, 80, 60, dan 50. Dari ilustrasi tersebut maka jelaslah IPM masih merupakan gambaran yang masih kasar untuk dapat dipakai sbagai representasi kondisi pembangunan manusia di suatu wilayah. Berdasarkan fakta tersebut maka perlu dilakukan suatu analisis yang lebih komprehensif untuk melihat hal tersebut yaitu tidak sekedar melihat nilai IPM tetapi harus melihatnya lebih kedalam dengan memanfaatkan informasi dari dimensi penyusun IPM tersebut.

Berdasarkan data yang didapat dari Badan Pusat Statistik (BPS) di Provinsi Bali didapat perkembangan dan nilai Indikator Penyusun IPM dari tahun 2010 sampai dengan tahun 2017, seperti terlihat pada tabel 3.2.1

Tabel 1. IPM dan Indikator Penyusunnya di Bali tahun 2010 - 2017

\begin{tabular}{|c|c|c|c|c|c|c|c|c|c|}
\hline Penyusun & Satuan & $\mathbf{2 0 1 0}$ & $\mathbf{2 0 1 1}$ & $\mathbf{2 0 1 2}$ & $\mathbf{2 0 1 3}$ & $\mathbf{2 0 1 4}$ & $\mathbf{2 0 1 5}$ & $\mathbf{2 0 1 6}$ & $\mathbf{2 0 1 7}$ \\
\hline $\begin{array}{c}\text { Umur Hara- } \\
\text { pan Hidup } \\
\text { (UHH) }\end{array}$ & tahun & 70,61 & 70,78 & 70,94 & 71,11 & 71,20 & 71,35 & 71,41 & 71,46 \\
\hline $\begin{array}{c}\text { Harapan } \\
\text { Lama } \\
\text { Sekolah } \\
\text { (HLS) }\end{array}$ & tahun & 11,71 & 12,12 & 12,26 & 12.40 & 12,64 & 12,97 & 13,04 & 13,21 \\
\hline $\begin{array}{c}\text { Rata-rata } \\
\text { Lama } \\
\text { Sekolah } \\
\text { (RLS) }\end{array}$ & tahun & 7.74 & 7,77 & 8,05 & 8,10 & 8,11 & 8,26 & 8,36 & 8,55 \\
\hline $\begin{array}{c}\text { Pengeluaran } \\
\text { Perkapita } \\
\text { (PP) }\end{array}$ & Rp.00 & 12,07 & 12,307 & 12,530 & 12,738 & 12,841 & 13,078 & 13,279 & 13,573 \\
\hline
\end{tabular}

Dari Tabel 1 Terlihat bahwa pertumbuhan IPM di Bali dari tahun 2010 - 2017 yang terjadi ternyata disumbangkan juga oleh kenaikan pada setiap penyusunnya pada setiap tahun. Pertanyaannya kemudian apa yang terjadi pada setiap kabupaten/kota yang ada di Bali? Data menunjukkan pada 2 (dua) tahun terakhir dapat dilihat pada Tabel 2. 
Tabel 2. IPM dan Penyusunnya Pada setiap kabupaten/ kota di Bali

\begin{tabular}{|c|c|c|c|c|c|c|c|c|c|c|c|}
\hline Provinsi & \multicolumn{2}{|c|}{$\begin{array}{c}\text { UHH (Ta- } \\
\text { hun) }\end{array}$} & \multicolumn{2}{c|}{$\begin{array}{c}\text { HLS (Ta- } \\
\text { hun) }\end{array}$} & \multicolumn{2}{c|}{$\begin{array}{c}\text { RLS (Ta- } \\
\text { hun) }\end{array}$} & \multicolumn{2}{c|}{$\begin{array}{c}\text { Pengeluaran per } \\
\text { Kapita (Rp000) }\end{array}$} & \multicolumn{2}{c|}{$\begin{array}{c}\text { IPM Ca- } \\
\text { paian }\end{array}$} & $\begin{array}{c}\text { Pertum- } \\
\text { buhan (\%) }\end{array}$ \\
\hline & 2016 & 2017 & 2016 & 2017 & 2016 & 2017 & 2016 & 2017 & 2016 & 2017 & $2016-2017$ \\
\hline Jembrana & 71,57 & 71,70 & 12,27 & 12,40 & 7,59 & 7,62 & 11.343 & 11.468 & 70,38 & 70,72 & 0,48 \\
\hline Tabanan & 72,89 & 73,03 & 12,87 & 12,95 & 8,10 & 8,43 & 13.800 & 13.923 & 74,19 & 74,86 & 0,90 \\
\hline Badung & 74,42 & 74,53 & 13,66 & 13,94 & 9,90 & 9,99 & 16.567 & 17.063 & 79,80 & 80,54 & 0,93 \\
\hline Gianyar & 72,95 & 73,06 & 13,36 & 13,37 & 8,86 & 8,87 & 13.766 & 14.222 & 75,70 & 76,09 & 0,52 \\
\hline Klungkung & 70,28 & 70,45 & 12,86 & 12,94 & 7,06 & 7,46 & 10.852 & 11.005 & 69,31 & 70,13 & 1,18 \\
\hline Bangli & 69,69 & 69,83 & 11,82 & 12,30 & 6,44 & 6,80 & 10.819 & 10.956 & 67,03 & 68,24 & 1,81 \\
\hline Karangasem & 69,66 & 69,85 & 12,33 & 12,38 & 5,48 & 5,52 & 9.690 & 9.833 & 65,23 & 65,57 & 0,52 \\
\hline Buleleng & 70,97 & 71,14 & 12,61 & 12,62 & 6,85 & 7,03 & 12.814 & 12.995 & 70,65 & 71,11 & 0,65 \\
\hline $\begin{array}{c}\text { Kota } \\
\text { Denpasar }\end{array}$ & 74,04 & 74,17 & 13,76 & 13,97 & 11,14 & 11,15 & 19.084 & 19.364 & 82,58 & 83,01 & 0,52 \\
\hline
\end{tabular}

Dari Tabel 2. tidak terlihat dengan jelas bagaimana posisi kontribusi penyusun IPM terhadap nilai IPM terutama untuk posisi IPM yang satu kelompok. Untuk lebih memperjelas gambaran tersebut maka dalam tulisan ini akan dilaporkan hasil analisis Biplot yang memungkinkan untuk mendapatkan posisi relatif dari masing-masing kabupaten/kota dengan yang lain berdasarkan variabel penyusunnya secara bersama - sama. Hasil ini kemudian dikomparasi dengan pengelompokan yang didapat berdasarkan IPM saja. Untuk mempertegas hasil analisis Biplot maka juga akan dilakukan analisis gerombol untuk medapatkan gambaran kelompok yang terjadi.

\subsection{Hasil Analisis Biplot dan Analisis Gerombol}

Untuk lebih memperjelas kedekatan antar obyek (kabubaten/kota) dengan mempertimbangkan kondisi dari variabel penyusunnya maka dilakukan anaisis biplot dengan menumpangtidihkan gambaran obyek dan peubah dalam satu grafik dua dimensi. Adapun hasil analisis biplot yang didapat adalah seperti yang digambarkan pada gambar 5.3.1

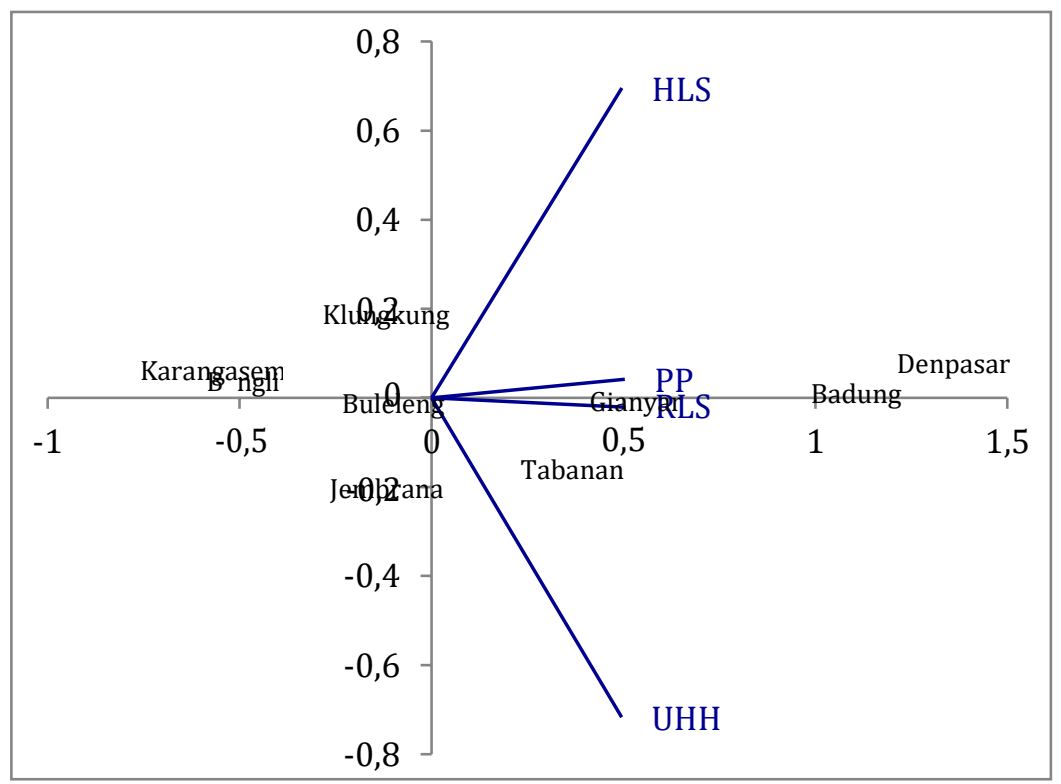

Gambar 4. Grafik Biplot Indikator Penyusun IPM Bali di Setiap Kabupaten/Kota 
Dari Gambar 4, terlihat bahwa berdasarkan variabel penyusunnya terlihat bahwa dari gambaran IPM sebelumnya bahwa Kabupaten Badung dan Denpasar jadi satu kelompok ternyata tergambar juga dari grafik biplot ini. Demikian juga terlihat Karangasem dan Bangli merupakan kabupaten yang relatif paling mungkin satu kelompok. Tetapi dari grafik tersebut dari ciri arah variabel dua kabupaten tersebut ada kecendrungan satu kelompok juga dengan Klungkung, Buleng dan Jembrana, sedangkan dilain fihak Tabanan dan Gianyar berada pada kelompok lain. Hal terjadi jika pengelompokan dibuat menjadi 3 kelompok seperti yang terjadi pada pengelompokan dilihat dari IPM terdahulu. Yang menarik dari gambaran di atas selain pengelompokan obyek yang sedikit berbeda juga terdapat informasi tentang adanya korelasi yang sangat erat antara variabel Rata-rata Lama Sekolah (RLS) dan Pengeluaran Perkapita (PP) Hal in cukup menarik karena awalnya diduga RLS akan paling berkorelasi dengan Harapan Lama Sekolah (HLS) yang sama - sama merupakan indikator pendidikan. Hal ini mungkin karena Harapan Lama Sekolah bukan fakta nyata tentang tingkat pendidikan yang digapai oleh masyarakat. Sehingga bias jadi antara harapan dan kenyataan tidak sinkron. Adanya korelasi yang erat antara RLS dan PP dapat dijelaskan karena wajar saja memang PP sebagai cermin pendapatan masyarakan sangat ditentukan tinggi rendahnya pendidikan masyarakat.

Untuk mempertegas pengelompokan yang sebenarnya maka gambaran biplot akan coba dilengkapi dengan analisis gerombol dimana analisis ini akan menggambarkan kelompok yang terjadi dengan melihat kedekatan antar obyek. Hasil pengelompokan dengan mensetting menjadi tiga kelompok didapat hasil berupa dendogram seperti pada Gambar 5.

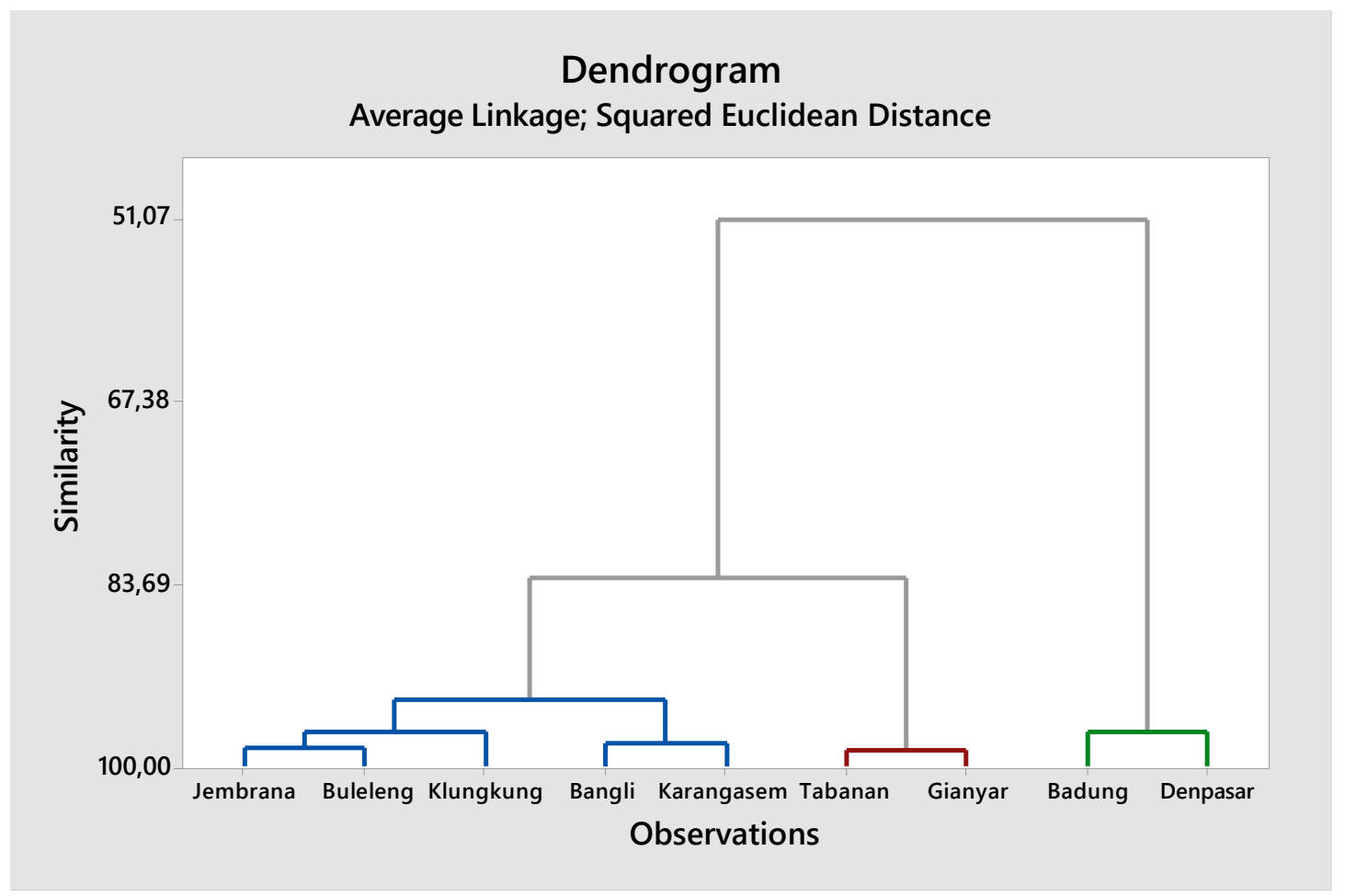

Gambar 5. Dendogram Pengelompokan Kabupaten/Kota di Bali Berdasarkan Variabel Penyusun IPM 
Jelas terlihat dari Gambar 5 bahwa jika dibuat 3 (tiga) kelompok maka seperti apa yang dijelaskan pada gambaran biplot ternyata kelompok yang terjadi agak sedikit berbeda dengan jika hanya memperhatikan IPM saja. Dengan dendogram ini terlihat bahwa kelompok yang terjadi adalah kelompok pertama yaitu Badung dan Denpasar; Kelompok kedua yaitu Tabanan dan Gianyar dan Kelompok terakhir adalah Jembrana , Buleleng, Klungkung, Bangli dan Karangasem. Pengelompokan ini terjadi dengan tingkat kesamaan minimal medekati 83\%. Yang Menarik jika kelompok dibuat menjadi 4 (empat kelompok maka hasilnya adalah kelompok pertama Badung dan Denpasar; Kelompok kedua Tabanan dan Gianyar; Keompok ketiga Jembrana, Buleleng dan Klungkung dan Kelompom terakhir adalah Bangli dan Karangasem. Kelompok ini terjadi jika kemiripannya minimal hampir $90 \%$.

\section{Simpulan dan Saran}

\subsection{Simpulan}

Berdasarkan pembahasan maka pada penelitian ini dapat disimpulkan sebagai berikut : Dengan melihat IPM saja maka Kabupaten. Kota di Bali tergolong dalam 3 (tiga) kelompok yaitu kelompok IPM sangat tinggi yaitu Kota Denpasar dan Kabupaten Badung; Kelompok IPM tinggi terdiri dari Kabupaten Tabanan, Buleleng, Jembrana, Gianyar dan Klungkung ; Kelompok IPM Sedang adalah Kabupaten Bangli dan Karangasem

Berdasarkan Analisis Biplot dan Analisis Gerombol dengan kemiripan minimal 83\% maka kelompok yang terbntuk adalah kelompok pertama Kota Denpasar dan Kabupaten Badung, Kelompok kedua Kabupaten Tabanan dan Gianyar dan Kelompok ketiga adalah Kabupaten Buleleng, Jembrana, Klungkung, Bangli dan Karangasem.

\subsection{Saran}

Penelitian ini bertujuan memotret Tingkat Kesejahteran Masyarakat di Provinsi Bali. Pada penelitian ini Indikator yang digunakan baru sebatas indicator penyusun IPM sebagai salah satu representasi kesejahteraan yang variabel pengukurnya tidak terlalu banyak. Untuk selanjutnya dapat disarankan dicoba memotret secara langsung dengan indikator yang lebih banyak terutama dengan menambah indicator pengukur pada aspek kesehatan dan pendapatan masyarakat

\section{Daftar Pustaka}

[1] BPS Propinsi Bali. 2018. Berita Resmi Statistik : Indeks Pembangunan Manusia 2017.

[2] Denpasar. BPS Provinsi Bali. 2005. Statistik Pendidikan Hasil Sensus Sosial Ekonomi Nasional 2005.Denpasar.

[3] BPS. 2017. Indikator Kesejahteraan Rakyat 2017. Jakarta.

[4] Dillon, W.R and Matthew, G. 1984. Multivariate Analysis Methode and Application. John Wiley and Sons, Inc. Canada. 
[5] Gabriel, K.R. 2002. Goodness of Fit of Biplots and Correspondence Analysis.ProQuest Science Journals. pp. 423-436.

[6] Lipkovich, I and Eric P.S. 2002. Biplot and Singular Value Decomposition Macros for $E x-c e l^{\complement}$. http://www.jstatsoft.org/v07/i05/BIPLOT_paper_6_6_02.pdf. Diakses Selasa, 10 Juli2007.

[7] Morrison, D.F. 2005. Multivariate Statistical Methods. Fourth Edition. Thompson Brooks/Cole. Can- ada.

[8] Watkins, D.S. 1991. Fundamentals of Matrix Computations. John Wiley and Sons, Inc. Singapore. 